\title{
Physical Activity Does Not Provide Health Benefits in Young Only: Advocating to Engage seniors to Get an Active Lifestyle
}

\author{
${ }^{*}$ Walid Bouaziz ${ }^{1,2}$, Thomas Vogel ${ }^{1,2}$, Elise Schmitt ${ }^{1,2}$, Georges Kaltenbach ${ }^{1}$, Bernard Geny ${ }^{2,3}$ and Pierre 0 livier \\ Lang $^{4,5}$ \\ ${ }^{1}$ Department of Geriatric, University Hospital, France
}

${ }^{2}$ Department of physiology, Strasbourg University, France

${ }^{3}$ Department of Functional Explorations, University Hospital, France

${ }^{4}$ Health and Wellbeing Academy, Anglia Ruskin University, United Kingdom

${ }^{5}$ Department of Geriatric and Rehabilitation Geriatric Division, University Hospital of Lausanne (CHUV), Switzerland

Submission: February 15, 2017; Published: February 20, 2017

*Corresponding author: Walid Bouaziz, Geriatric Department, University Hospital, 83 rue Himmerich, 67091 Strasbourg, cedex, France, Tel: +33 (0) 3.88.11.55.24; Fax: +33 (0) 3.88.11.58.21; Email: walid.bouaziz.88@gmail.com

\section{Editorial}

In the last century, western societies have experienced a demographic shift towards an ever-increasing aging population. Over the last half-century the number of adults aged 70 or over has simply tripled; and by 2025-2030, this population wills begrowing 3.5 times as rapidly as the general population [1]. Europe may currently lead the world with the highest proportions of older individuals, but this may not last much longer [2]. By 2050, nearly four-fifths of the world's older popu 1 lation will be living in the developing and less-developed regions of the world. Whilst the ageing of the general population is one of the humanity's greatest triumphs, it also confronts societies with enormous medical challenges [3]. Indeed, lengthening lifespan is not necessarily synonymous with extending life in good health and studies suggested that with advancing age chronic and degenerative disorders became more and more prevalent and that multimorbidity is increasing [4]. In addition, it is observed a progressive decline in disability-free life which in turn is associated with an increase in the requirement for assisted living in order for older individuals to perform basic activities of daily living [4]. In parallel, some recent publications and studies highlighting the poor participation rate of seniors in sportive recreational activities [5], and very few were older adults who drive an active lifestyle in the line of the recommendations edited by the American College of Sports Medicine [6].

According to World Health Organization (WHO), 60 to $85 \%$ of general population worldwide has a sedentary lifestyle, making it one of the more serious, but yet insufficiently, addressed public health problems. This issue does not spare the ageing and aged adult population where sedentary behavior is also highly prevalent [7]. Indeed, nowadays physical inactivity, along with poor diet and nutrition, and persisting tobacco use are well fixed in the modern lifestyle leading to the rapid rise of non-communicable and chronic diseases, which are now the first causes of mortality in every part of world. Sedentary lifestyles double the risk of cardiovascular diseases, diabetes, and obesity, and increase the risks of colon cancer, hypertension, serum lipid profile disorders, osteoporosis, and mood disorders anxiety, and finally global mortality [8-10]. Among the preventive measures recommended by WHO for non-communicable diseases is, in addition, of course, to tobacco cessation and healthy nutrition (including moderate alcohol consumption) to engage people to get at least 30 minutes of moderate physical activity every single day. In addition, governments and policy makers are recommended to generate supportive environments in order to facilitate the population's engagement in this active lifestyle [7].

There is an abundant literature supporting the benefits of regular physical activity on human's health. Regardless of age, active lifestyle is an important component of healthy and active ageing, both in relation to staying fit and healthy, and also as a way to stay mobile and socially included[11,12]. A recent Cochrane systematic review confirmed that aerobic exercise interventions resulted in increased fitness and an improvement in cognitive function in healthy people aged 55 years or over [13]. However, even later in life, evidence suggests that regular 
physical activity is not only feasible but also favors physiologic improvements in terms of breaking down and even reversing the age-related decline of cardio-respiratory performances, and mobility and balance [14]. Hence, regular physical activity contributes to extend the period of active and free-disability life [15] and to delay cognitive impairments, and improve the QoL $[16,17]$.

With this aim and perspective, aerobic training appear to be the most effective intervention for improving the overall health status among seniors. Recently, a narrative review of 36randomized, and 17 non-randomized controlled studies confirmed the above described benefits in people aged 70 years or over [18]. In the view of the global health benefits of aerobic training, definitely, general practitioners and physicians must encourage senior to engage and/or return to an active lifestyle. This will contribute to keep longer autonomous and independent in their daily life the frailer members of our society.

\section{References}

1. Lutz W, Sanderson W, Scherbov S (1997) Doubling of world population unlikely. Nature 387: 803-805.

2. World population ageing (2013) United nations, New York.

3. Lang PO, Dramé M (2013) Demographical ageing: How can we measure the quality of our future? Neurol Psychiatr Geriatr 13: 256-266.

4. St Sauver JL, Boyd CM, Grossardt BR, Bobo WV, Finney Rutten LJ, et al. (2015) Risk of developing multimorbidity across all ages in an historical cohort study: differences by sex and ethnicity. BMJ Open 5(2): e006413.

5. Taylor D (2014) Physical activity is medicine for older adults. Postgrad Med J 90(1059): 26-32.

6. Nelson ME, Rejeski WJ, Blair SN, Duncan PW, Judge JO, et al. (2007) Physical activity and public health in older adults: recommendation from the American College of Sports Medicine and the American Heart Association. Med Sci Sports Exerc 116(9): 1094-1105.
7. World Health Organization (WHO) (2010) Global status report on non communicable diseases, Geneva Switzerland.

8. Vogel T, Leprêtre PM, Brechat PH, Lonsdorfer E, Benetos A, et al. (2011) Effects of a short-term personalized Intermittent Work Exercise Program (IWEP) on maximal cardio-respiratory function and endurance parameters among healthy young and older seniors. J Nutr Health Aging 15(10): 905-911.

9. Dogra S, Stathokostas L (2012) Sedentary behavior and physical activity are independent predictors of successful aging in middle-aged and older adults. J Aging Res 190654

10. Thorp AA, Owen N, Neuhaus M, Dunstan DW (2011) Sedentary behaviors and subsequent health outcomes in adults a systematic review of longitudinal studies, 1996-2011. Am J Prev Med41(2): 207215 .

11. Rice DP, Fineman N (2004) Economic implications of increased longevity in the United States. Annu Rev Public Health 25: 457-473.

12. Denton FT, Spencer BG (2010) Chronic health conditions: changing prevalence in an aging population and some implications for the delivery of health care services. Can J Aging29(1): 11-21.

13. Young J, Angevaren M, Rusted J, Tabet N (2015) Aerobic exercise to improve cognitive function in older people without known cognitive impairment. Cochrane Database Syst Rev 22(4): CD005381.

14. Hollmann W, Strüder HK, Tagarakis CVM, King G (2007) Physical activity and the elderly. Eur J Cardiovasc Prev Rehabil Off J Eur Soc Cardiol Work Groups Epidemiol Prev Card Rehabil Exerc Physiol 14: 730-739.

15. Acree LS, Longfors J, Fjeldstad AS, Fjeldstad C, Schank B, et al. (2006) Physical activity is related to quality of life in older adults. Health Qual Life Outcomes 4: 37. doi:10.1186/1477-7525-4-37.

16. Vogel T, Brechat PH, Leprêtre PM, Kaltenbach G, Berthel M, et al. (2009) Health benefits of physical activity in older patients: a review. Int J Clin Pract 63(2): 303-320.

17. Fleg JL (2012) Aerobic exercise in the elderly: a key to successful aging. Discov Med13(70): 223-228.

18. Bouaziz W, Vogel T, Schmitt E, Kaltenbach G, Geny B, et al. (2017) Health benefits of aerobic training programs in adults aged 70 and over: a systematic review. Arch Gerontol Geriatr 69: 110-127.

\section{Your next submission with Juniper Publishers will reach you the below assets}

- Quality Editorial service

- Swift Peer Review

- Reprints availability

- E-prints Service

- Manuscript Podcast for convenient understanding

- Global attainment for your research

- Manuscript accessibility in different formats

( Pdf, E-pub, Full Text, Audio)

- Unceasing customer service

Track the below URL for one-step submission https://juniperpublishers.com/online-submission.php 